\title{
Hypomagnesemia is not an independent risk factor for mortality in Japanese maintenance hemodialysis patients
}

\author{
Sonoo Mizuiri ${ }^{1} \cdot$ Yoshiko Nishizawa $^{1} \cdot$ Kazuomi Yamashita $^{1} \cdot$ Takayuki Naito $^{1} \cdot$ Kyoka Ono $^{1} \cdot$ Chie Tanji $^{2} \cdot$ Koji Usui $^{2}$. \\ Shigehiro Doi $^{3} \cdot$ Takao Masaki $^{3} \cdot$ Kenichiro Shigemoto $^{1}$
}

Received: 15 May 2018 / Accepted: 3 January 2019 / Published online: 11 April 2019

(c) The Author(s) 2019

\begin{abstract}
Purpose It is unclear whether hypomagnesemia is an independent risk factor or innocent bystander for mortality in maintenance hemodialysis (MHD) patients. Thus, we studied associations between hypomagnesemia and all-cause as well as cardiovascular (CV) mortality in MHD patients.

Methods Baseline clinical characteristics and coronary artery calcium score (CACS) of 353 Japanese MHD patients were reviewed. Three-year survival rate and mortality risk factors were assessed.

Results Median (interquartile range) age, dialysis vintage, serum magnesium (Mg), serum albumin and CACS of the subjects were 68 (60-78) years, 75 (32-151) months, 2.4 (2.2-2.7) mg/dl, 3.6 (3.3-3.8) g/dl, and 1181 (278-3190), respectively. During the 3-year period, 91 patients died. Kaplan-Meier overall 3-year survival rates were $59.0 \%$ in in patients with $\mathrm{Mg}<2.4 \mathrm{mg} / \mathrm{dl}(n=136)$ and $82.3 \%$ in patients with $\mathrm{Mg} \geq 2.4 \mathrm{mg} / \mathrm{dl}(n=217),(P<0.0001)$. In Cox regression models not incorporating serum albumin, $\mathrm{Mg}<2.4 \mathrm{mg} / \mathrm{dl}$ was significantly associated with 3-year all-cause death, independent of age, dialysis vintage, average ultrafiltration, $\log (\mathrm{CACS}+1)$, warfarin use, serum potassium, high-sensitivity C-reactive protein (hsCRP), phosphate, uric acid, and intact parathyroid hormone [Hazard ratio (HR) 95\% confidence interval (CI): 2.82 (1.31-6.29), $P=0.0078]$, and CV death, independent of age, dialysis vintage, Log (CACS + 1), warfarin use, serum hsCRP, and uric acid [HR (95\% CI): 4.47 (1.45-16.76), $P=0.0086$ ]. Nevertheless, associations of $\mathrm{Mg}<2.4 \mathrm{mg} / \mathrm{dl}$ with all-cause and $\mathrm{CV}$ mortality were all absent in models that included serum albumin.

Conclusions Hypomagnesemia is not an independent risk factor for mortality but is associated with malnutrition in MHD patients.
\end{abstract}

Keywords Coronary artery calcium score $\cdot$ Hemodialysis $\cdot$ Hypomagnesemia $\cdot$ Malnutrition $\cdot$ Mortality

\section{Introduction}

Vascular calcification is common in hemodialysis (HD) patients and increases the risk of cardiovascular (CV) disease [1]. Recently, interest has grown in the relationships between serum magnesium $(\mathrm{Mg})$ levels and vascular calcification or mortality in HD patients [2]. Extracellular

Sonoo Mizuiri

sm210@med.toho-u.ac.jp

1 Division of Nephrology, Ichiyokai Harada Hospital, 7-10 Kairoyama-cho, Saeki-ku, Hiroshima 731-5134, Japan

2 Ichiyokai Ichiyokai Clinic, 10-3 Asahien, Saeki-ku, Hiroshima 731-5133, Japan

3 Department of Nephrology, Hiroshima University Hospital, 1-2-3 Kasumi Minami-ku, Hiroshima 734-8551, Japan magnesium accounts for only $1 \%$ of the total body content $[3,4]$. Serum contains a much smaller amount $(0.3 \%$ of total body stores), of which one-third is bound to protein, and nonprotein bound magnesium is the fraction that is ultrafilterable in HD and consists of complexed and free magnesium (5.5\% and $61 \%$ of total serum levels, respectively) [4]. Normal $\mathrm{Mg}$ concentration is $1.7-2.4 \mathrm{mg} / \mathrm{dl}$, and magnesium homeostasis is determined by the balance between absorption and excretion (intestinal and renal) [3, 4]. In experimental studies, magnesium inhibited vascular calcification and osteogenic differentiation in vitro [5], prevented calciprotein particle maturation, which can induce calcification in vitro [6], and bound to phosphate in the intestines, which reduced vascular calcification in rats [7]. In clinical studies, the follow-up periods used in previous large studies have been short $[8,9]$; notably, few interventional studies have been 
performed $[2,10]$. Clinical studies have produced inconsistent results regarding the association between $\mathrm{Mg}$ levels and mortality, partly because hypomagnesemia is linked to an increased frequency of co-morbidities. It is unclear whether hypomagnesemia causes increased mortality as an independent risk factor or as an "innocent bystander" [11].

This study was undertaken to investigate the associations between hypomagnesemia and all-cause as well as CV mortality in maintenance hemodialysis (MHD) patients.

\section{Materials and methods}

This prospective observational study included 353 unselected patients that received MHD during September 2014 at Ichiyokai Hospitals. Patients who met any of the following criteria were excluded: age $<20$ years old, had been on dialysis for $<3$ months, had a history of advanced cancer, had experienced an infection in the past month, or had undergone organ transplantation. All patients underwent 4-h HD sessions, with high-flux membranes and standard bicarbonate dialysis fluid $(140 \mathrm{mEq} / \mathrm{l}$ sodium, $2.0 \mathrm{mEq} / \mathrm{l}$ potassium, $3.0 \mathrm{mEq} / \mathrm{l}$ calcium, $1.0 \mathrm{mEq} / 1 \mathrm{magnesium}$, and $100 \mathrm{mg} / \mathrm{dl}$ glucose) using central dialysis fluid delivery system, 3 times per week. Patients' baseline characteristics, including information regarding age, gender, primary kidney disease, dialysis vintage, presence of diabetes mellitus, and current use of warfarin, were obtained from the institutional database. Blood pressure values, $\mathrm{Kt} /$ Vurea, $\mathrm{Mg}$, serum albumin, high-sensitivity C-reactive protein (hsCRP), potassium, phosphate, uric acid, intact parathyroid hormone (iPTH), intact fibroblast growth factor 23 (FGF23), albumin-adjusted serum calcium levels, normalized protein nitrogen appearance (nPNA), and geriatric nutritional risk index (GNRI) were measured at baseline, just before or after (for Kt/Vurea alone) the first dialysis session of the first week in September 2014. Furthermore, 24-h urinary volume was evaluated 1 day before baseline blood sampling. Urine volume $\geq 100 \mathrm{ml} /$ day was used as a surrogate marker for residual renal function; no residual renal function was defined as urine volume $<100 \mathrm{ml} /$ day in this study. The average ultrafiltration/body weight before treatment in the first hemodialysis session of the week in September 2014 (ml/ $\mathrm{kg} / \mathrm{h}$ ) was also evaluated. The coronary artery calcium score (CACS) was assessed using the Agatston score [12], which was obtained from thoracoabdominal multi-detector computed tomography with an Aquilion 64 TSX-101A (Toshiba Medical Systems, Tokyo, Japan). The all-cause and CV mortalities during the follow-up period (from September 2014 to September 2017) were confirmed based on documentation. The CV mortality rate was calculated based on deaths due to $\mathrm{CV}$ disease (coronary artery disease, aortic aneurysms, cerebral infarction, cerebral hemorrhage, and/or peripheral artery disease). Patients were followed until death or the end of the study (for 1095 days); their Mg and serum hsCRP levels were determined by BML, Inc. (Tokyo, Japan). A colorimetric method for quantitative $\mathrm{Mg}$ determination (Clonemate MG reagent; Sekisui Medical, Tokyo, Japan) was used, which has a normal range of 1.7 to $2.4 \mathrm{mg} / \mathrm{dl}$ in the general population and a coefficient of variation of approximately $0.83-1.71 \%$. Serum FGF23 levels were determined by SRL, Inc. (Tokyo, Japan), which used a sandwich enzyme-linked immunosorbent assay kit (Kainos Laboratories, Tokyo, Japan). Our hospital's laboratory performed the remaining clinical biochemical analyses.

\section{Statistical analysis}

All statistical analyses were performed with JMP 13 (SAS Institute Japan, Tokyo, Japan). Data for categorical variables are shown as numbers of patients (percentages); data for continuous variables are shown as mean \pm standard deviation (SD) or median values and interquartile range (IQR), as appropriate. The significance of inter-group differences was analyzed with the Kruskal-Wallis test, or $\chi^{2}$ test, as appropriate. Kaplan-Meier 3-year cumulative survival for all-cause deaths and CV deaths was compared between patients with $\mathrm{Mg}$ level below the median value and patients with $\mathrm{Mg}$ level above the median value in all subjects and subgroups according to serum albumin quartiles. Hazard ratios (HRs) for all-cause and $\mathrm{CV}$ death, with associated 95\% confidence intervals (CIs), were calculated with the use of a stratified Cox proportional-hazards model. Univariate and multivariate Cox proportional-hazards models were used to determine the factors associated with 3-year all-cause and CV mortality. The distributions of FGF23 and CACS were markedly skewed. Prior to the Cox proportional hazards analyses, FGF23 was transformed to Log FGF23 and CACS was transformed to $\log (\mathrm{CACS}+1)$, because some of the study participants had a CACS of 0 .

\section{Results}

The MHD patients' primary diseases were as follows: diabetic nephropathy $(n=142,40.2 \%)$, chronic glomerulonephritis $(n=121,34.3 \%)$, nephrosclerosis $(n=43,12.2 \%)$, polycystic kidney disease $(n=11,3.1 \%)$, other diseases ( $n=13,3.7 \%)$, and unknown conditions $(n=23,6.5 \%)$. The baseline characteristics of the patients are shown in Table 1. Among all patients $(n=353)$, the median (IQR) age was $68(60-78)$ years and $66.6 \%$ were male. The median (IQR) dialysis vintage was 75 (32-151) months. The median (IQR) $\mathrm{Mg}$ level was 2.4 (2.2-2.7) $\mathrm{mg} / \mathrm{dl}$; four (1.1\%) patients had 
Table 1 Baseline characteristics of maintenance hemodialysis patients $(n=353)$, stratified by the serum magnesium value

\begin{tabular}{|c|c|c|c|c|c|c|}
\hline \multirow[t]{2}{*}{ Characteristics } & \multirow{2}{*}{$\begin{array}{l}\text { All } \\
n=353\end{array}$} & \multirow{2}{*}{$\begin{array}{l}\text { Group } 1 \\
(\mathrm{Mg}<2.2 \mathrm{mg} / \mathrm{dl}) \\
n=86\end{array}$} & \multirow{2}{*}{$\begin{array}{l}\text { Group } 2 \\
(\mathrm{Mg} 2.2-2.4 \mathrm{mg} / \mathrm{dl}) \\
n=97\end{array}$} & \multirow{2}{*}{$\begin{array}{l}\text { Group } 3 \\
(\mathrm{Mg} 2.5-2.7 \mathrm{mg} / \mathrm{dl}) \\
n=99\end{array}$} & \multirow{2}{*}{$\begin{array}{l}\text { Group } 4 \\
(\mathrm{Mg}>2.7 \mathrm{mg} / \mathrm{dl}) \\
n=71\end{array}$} & \multirow[t]{2}{*}{$P$} \\
\hline & & & & & & \\
\hline Serum magnesium $(\mathrm{mg} / \mathrm{dl})$ & $2.4(2.2-2.7)$ & $2.0(1.9-2.1)$ & $2.3(2.2-2.4)$ & $2.6(2.5-2.7)$ & $2.9(2.8-3.1)$ & $<0.0001$ \\
\hline Age (years) & $68(60-78)$ & $73(64-80)$ & $71(62-79)$ & $66(59-73)$ & $63(55-73)$ & $<0.0001$ \\
\hline Gender (male), $n(\%)$ & $235 / 353(66.6)$ & $62 / 86(72.1)$ & $62 / 97(63.9)$ & $66 / 99(66.7)$ & $45 / 71(63.4)$ & 0.6126 \\
\hline Dialysis vintage (months) & $75(32-151)$ & $55(23-105)$ & $60(28-126)$ & $85(46-175)$ & $93(48-183)$ & 0.0044 \\
\hline Diabetes mellitus, $n(\%)$ & $142 / 353(40.2)$ & $41 / 86(47.7)$ & $37 / 97(38.1)$ & $36 / 99(36.7)$ & 28/71 (39.4) & 0.4454 \\
\hline Urine volume $\geq 100 \mathrm{ml} / \mathrm{day}, n(\%)$ & $87 / 353(24.6)$ & $20 / 86(23.2)$ & $31 / 97(32.0)$ & $21 / 99(21.2)$ & $15 / 71(21.1)$ & 0.2631 \\
\hline Average ultrafiltration $(\mathrm{ml} / \mathrm{kg} / \mathrm{h})$ & $11.2 \pm 3.1$ & $10.4 \pm 3.5$ & $11.0 \pm 2.8$ & $11.7 \pm 2.6$ & $11.8 \pm 3.5$ & 0.0122 \\
\hline CACS & $1181(278-3190)$ & $1550(318-3715)$ & $1145(254-2872)$ & $1030(247-2520)$ & $1057(257-2357)$ & 0.5483 \\
\hline Warfarin use, $n(\%)$ & $39 / 353(11.0)$ & $15 / 86(17.4)$ & $4 / 97(4.1)$ & $15 / 99(15.1)$ & $5 / 71(7.0)$ & 0.0109 \\
\hline Serum potassium $(\mathrm{mEq} / \mathrm{l})$ & $4.7 \pm 0.8$ & $4.3 \pm 0.8$ & $4.6 \pm 0.7$ & $5.0 \pm 0.7$ & $5.0 \pm 0.8$ & $<0.0001$ \\
\hline Serum hsCRP (mg/dl) & $0.12(0.04-0.43)$ & $0.26(0.06-0.80)$ & $0.12(0.03-1.49)$ & $0.12(0.03-0.35)$ & $0.07(0.03-0.19)$ & $<0.0008$ \\
\hline Serum phosphate (mg/dl) & $5.1(4.1-6.0)$ & $4.2(3.2-5.4)$ & $5.2(4.2-6.1)$ & $5.3(4.7-6.3)$ & $5.1(4.4-6.1)$ & $<0.0001$ \\
\hline Serum uric acid (mg/dl) & $7.3 \pm 1.4$ & $6.6 \pm 1.4$ & $7.4 \pm 1.4$ & $7.4 \pm 1.1$ & $7.6 \pm 1.5$ & $<0.0001$ \\
\hline $\begin{array}{l}\text { Serum intact parathyroid hor- } \\
\text { mone }(\mathrm{pg} / \mathrm{ml})\end{array}$ & $109(51-208)$ & $107(49-183)$ & $110(57-210)$ & $128(60-241)$ & $97(38-183)$ & 0.1247 \\
\hline Serum albumin $(\mathrm{g} / \mathrm{dl})$ & $3.6(3.3-3.8)$ & $3.3(2.9-3.6)$ & $3.6(3.3-3.8)$ & $3.6(3.4-3.8)$ & $3.7(3.5-3.9)$ & $<0.0001$ \\
\hline FGF23 (pg/ml) & $3165(590-11075)$ & $784(247-5510)$ & $3210(769-11650)$ & $4470(1305-13425)$ & $4680(1150-11500)$ & $<0.0001$ \\
\hline
\end{tabular}

$\mathrm{Mg}$, serum magnesium; Diabetes mellitus, presence of diabetes mellitus; Average ultrafiltration (ml $/ \mathrm{kg} / \mathrm{h}$ ), average ultrafiltration/body weight before treatment in the first hemodialysis session of the week in September $2014(\mathrm{ml} / \mathrm{kg} / \mathrm{h}) ; \mathrm{CACS}$, coronary artery calcium score; Warfarin use, current use of warfarin; hsCRP, high-sensitivity C-reactive protein; FGF23, intact fibroblast growth factor 23

$\mathrm{Mg}<1.7 \mathrm{mg} / \mathrm{dl}, 179$ (50.7\%) patients had Mg values in the normal range for the general population $(1.7-2.4 \mathrm{mg} / \mathrm{dl})$, and $170(48.2 \%)$ patients had $\mathrm{Mg}>2.4 \mathrm{mg} / \mathrm{dl}$. The same $\mathrm{Mg}$ values were observed in many patients in this study, and the groups were not correctly divided into quartiles; notably, the four groups according to $\mathrm{Mg}$ differed considerably in the numbers of patients. Mg levels were $<2.2 \mathrm{mg} /$ $\mathrm{dl}, 2.2-2.4 \mathrm{mg} / \mathrm{dl}, 2.5-2.7 \mathrm{mg} / \mathrm{dl}$, and $>2.7 \mathrm{mg} / \mathrm{dl}$ in group (G)1 $(n=86), \mathrm{G} 2(n=97), \mathrm{G} 3(n=99)$, and G4 $(n=71)$, respectively. Our study showed that age, dialysis vintage, average ultrafiltration, frequency of warfarin use, serum potassium, hsCRP, phosphate, uric acid, albumin, and FGF23 levels were significantly different among the four groups $(P<0.05)$. There were also significant differences in nPNA [0.80 (0.60-0.92), 0.89 (0.78-1.04), 0.94 $(0.83-1.05)$, and $0.97(0.85-1.11) \mathrm{g} / \mathrm{kg} / \mathrm{day}, P<0.0001]$, GNRI [89 (80-94), 92 (86-97), 94 (91-98), and 95 (89-98), $P<0.0001], \mathrm{Kt} /$ Vurea [1.30 (1.12-1.46), 1.40 (1.25-1.56), 1.41 (1.30-1.62), and $1.42(1.26-1.57) /$ session, $P=0.0003$ ], and diastolic blood pressure $[77 \pm 15,79 \pm 14,82 \pm 13$, and $83 \pm 14 \mathrm{mmHg}, P=0.0003$ ] in G1, G2, G3 and G4 (data not shown). No significant differences were detected among the four groups in the frequency of male gender, frequency of diabetes mellitus, frequency of urine volume $\geq 100 \mathrm{ml} /$ day,
CACS, or iPTH values. Furthermore, no significant differences were detected in albumin-adjusted serum calcium [9.4 (8.9-10.0), 9.3 (8.9-9.8), 9.5 (9.0-10.0), and 9.4 (9.1-10.1) $\mathrm{mg} / \mathrm{dl}, P=0.5318]$ and systolic blood pressure $[147 \pm 25$, $146 \pm 23,150 \pm 20$, and $154 \pm 22 \mathrm{mmHg}, P=0.2221]$ in G1, G2, G3 and G4 (data not shown).

Ninety-one patients died during the 3-year observation period, and the 3-year cumulative survival rate in all subjects was $73.3 \%$. CV disease $(51.6 \%, 47 / 91)$ was the primary cause of death, followed by infection $(30.8 \%, 28 / 91)$, malignancy $(3.3 \%, 3 / 91)$, other causes $(11.0 \%, 10 / 91)$, and unknown conditions $(3.3 \%, 3 / 91)$. Kaplan-Meier plots showed that 3-year overall survival for all-cause mortality was $59.0 \%$ in patients with $\mathrm{Mg}$ value below the median value $(<2.4 \mathrm{mg} / \mathrm{dl}, n=136)$ and $82.3 \%$ in patients with $\mathrm{Mg}$ value above the median value ( $\geq 2.4 \mathrm{mg} / \mathrm{dl}, n=217)$. The HR $(95 \%$ CI) for 3-year all-cause death in patients with $\mathrm{Mg}<2.4 \mathrm{mg} /$ dl was 2.79 (1.84-4.27), $P<0.0001$ (Fig. 1a). However, 3 -year cumulative survival for all-cause mortality in patients with $\mathrm{Mg}<2.4 \mathrm{mg} / \mathrm{dl}$ did not differ significantly from that of patients with $\mathrm{Mg} \geq 2.4 \mathrm{mg} / \mathrm{dl}$ in all subgroups that were analyzed, including those with serum albumin of quartile (Q)1 [3.0 (2.7-3.2) g/dl, $n=88$ ], serum albumin of Q2 [3.5 (3.4-3.5) $\mathrm{g} / \mathrm{dl}, n=88]$, serum albumin of Q3 [3.7 (3.6-3.7) 


\section{a Overall 3-year survival for all-cause mortality}

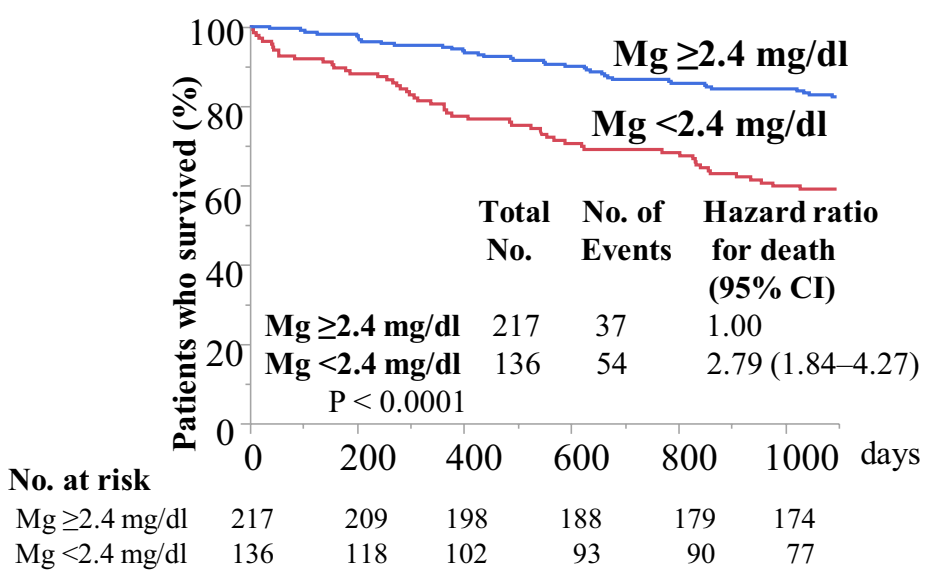

b Serum albumin of Q1: $3.0(2.7-3.2) \mathrm{g} / \mathrm{dl}$

d Serum albumin of Q3 : $3.7(3.6-3.7) \mathrm{g} / \mathrm{dl}$
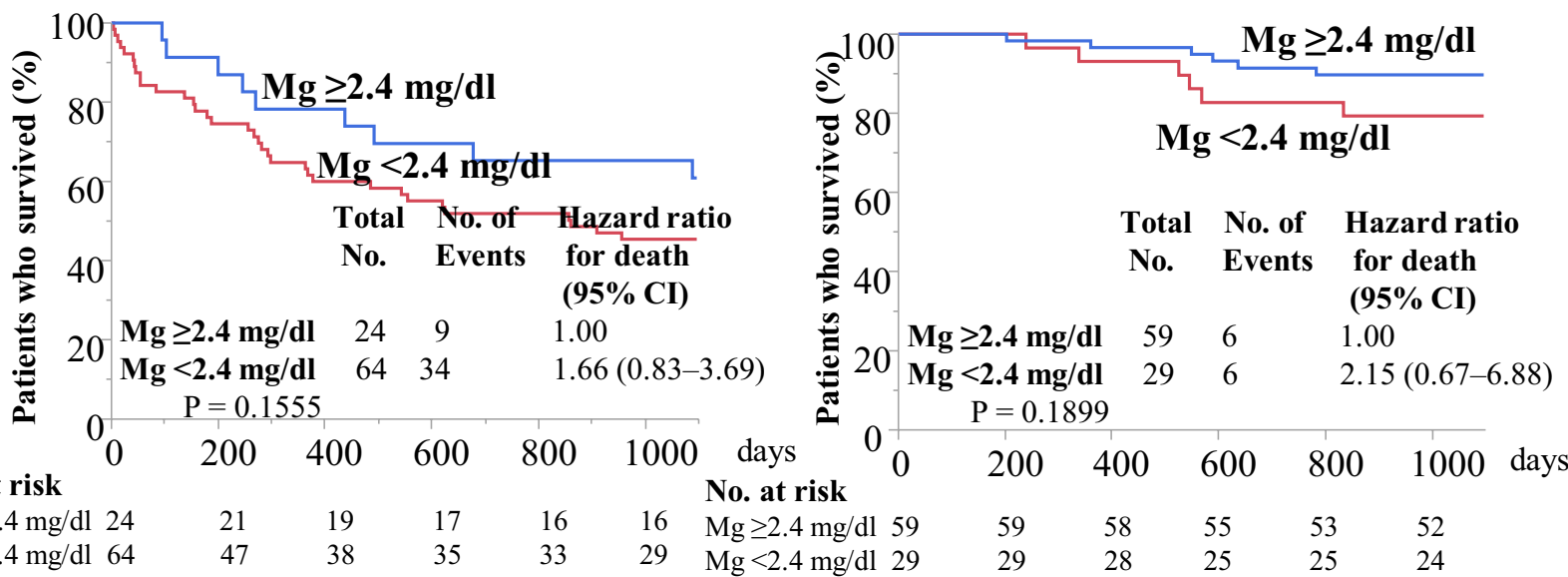

No. at risk

$\mathrm{Mg} \geq 2.4 \mathrm{mg} / \mathrm{dl} 24$

$\mathrm{Mg}<2.4 \mathrm{mg} / \mathrm{dl} 64$

$\begin{array}{ll}21 & 19 \\ 47 & 38\end{array}$

No, at risk

c Serum albumin of Q2: $3.5(3.4-3.5) \mathrm{g} / \mathrm{dl}$

e Serum albumin of Q4: $3.9(3.8-3.9) \mathrm{g} / \mathrm{dl}$
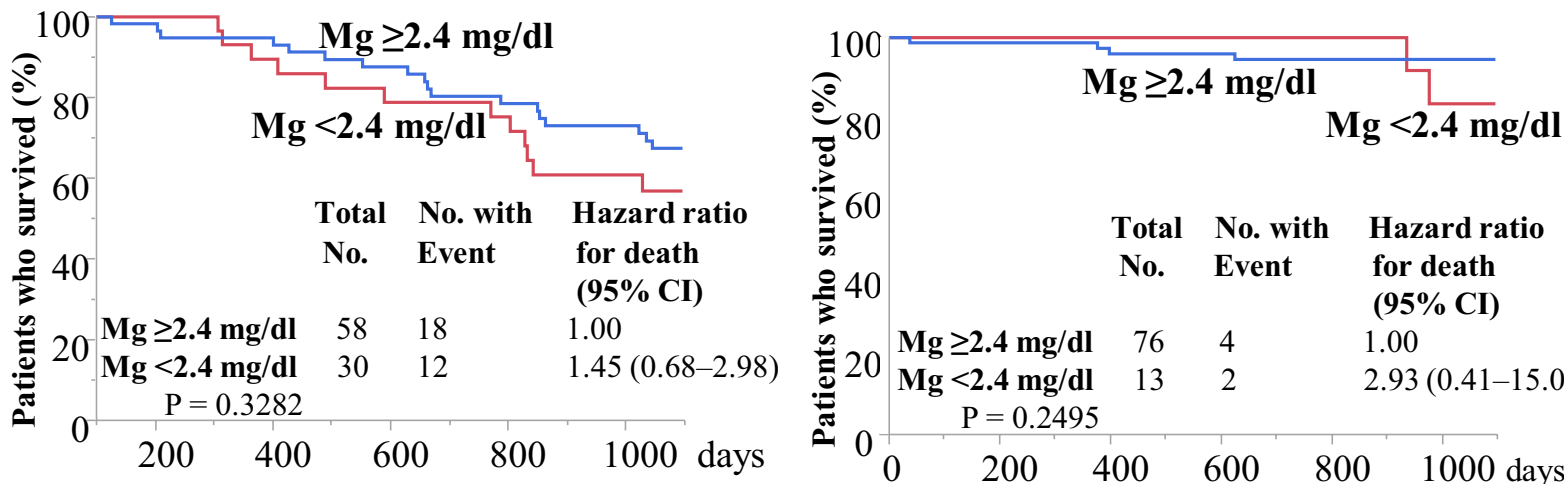

No, at risk

No. at risk

60

$\mathrm{Mg}<2.4 \mathrm{mg} / \mathrm{dl}$

$\mathrm{Mg} \geq 2.4 \mathrm{mg} / \mathrm{dl} 58$

$\mathrm{Mg}<2.4 \mathrm{mg} / \mathrm{dl} 30 \quad 30$

$\begin{array}{llll}54 & 49 & 44 & 40 \\ 26 & 23 & 22 & 16\end{array}$

No. at risk

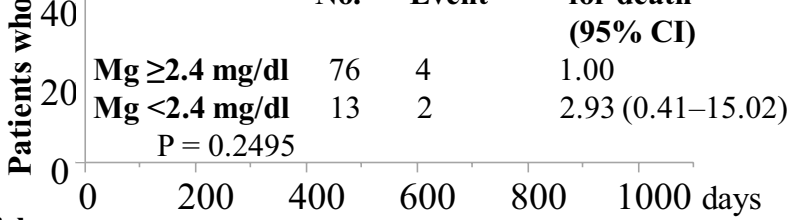

$\mathrm{Mg}<2.4 \mathrm{mg} / \mathrm{dl} 13$

$\begin{array}{lllll}73 & 70 & 70 & 69 & 69 \\ 13 & 13 & 13 & 13 & 11\end{array}$


४Fig. 1 Kaplan-Meier overall 3-year survival for all-cause death (a) and 3-year survival for all-cause death in subgroups according to serum albumin quartiles (b-e). Overall survival was worse in patients with $\mathrm{Mg}$ values below the median value $(<2.4 \mathrm{mg} / \mathrm{dl}, n=136)$ than in patients with $\mathrm{Mg}$ values above the median value $(\geq 2.4 \mathrm{mg} / \mathrm{dl}$, $n=217)$. The hazard ratio for death (95\% confidence interval) was 2.79 (1.84-4.27), $P<0.0001$ (a). However, the significant difference was lost in subgroup analyses according to serum albumin quartiles. $\mathrm{Mg}$, serum magnesium; No., numbers; $\mathrm{CI}$, confidence interval

$\mathrm{g} / \mathrm{dl}, n=88]$, and serum albumin of Q4 [3.9 (3.8-3.9) $\mathrm{g} / \mathrm{dl}$, $n=89$ ] (Fig. 1b-e).

Kaplan-Meier plots also showed significantly worse overall 3-year survival for CV mortality in patients with $\mathrm{Mg}<2.4 \mathrm{mg} / \mathrm{dl}(n=136)$, compared with that in patients with $\mathrm{Mg} \geq 2.4 \mathrm{mg} / \mathrm{dl}(n=217)$; the HR $(95 \% \mathrm{CI})$ for 3-year CV death in patients with $\mathrm{Mg}<2.4 \mathrm{mg} / \mathrm{dl}$ was 3.73 (2.07-6.98), $P<0.0001$ (Fig. 2a). However, 3-year cumulative survival for $\mathrm{CV}$ mortality in patients with $\mathrm{Mg}<2.4 \mathrm{mg} / \mathrm{dl}$ did not differ significantly from that of patients with $\mathrm{Mg} \geq 2.4 \mathrm{mg} / \mathrm{dl}$ in all subgroups that were analyzed, including those with serum albumin of Q1, Q2, Q3, and Q4 (Fig. 2b-e).

The predictors of 3-year all-cause mortality in MHD patients by Cox proportional hazard analyses are shown in Table 2. They included the age, dialysis vintage, average ultrafiltration, $\log (\mathrm{CACS}+1)$, warfarin use, serum potassium, hsCRP, phosphate, uric acid, iPTH, $\mathrm{Mg}<2.4 \mathrm{mg} /$ $\mathrm{dl}$, serum albumin, gender (male), presence of diabetes mellitus, urine volume $\geq 100 \mathrm{ml} / \mathrm{day}$, and Log FGF23 at baseline. In the univariate analyses, all variables except gender (male), presence of diabetes mellitus, urine volume $\geq 100 \mathrm{ml} /$ day, and Log FGF23 were significantly associated with 3 -year all-cause mortality $(P<0.05)$. In multivariate analyses, $\mathrm{Mg}<2.4 \mathrm{mg} / \mathrm{dl}$ was a significant all-cause mortality risk factor independent of age, dialysis vintage, average ultrafiltration, $\log (\mathrm{CACS}+1)$, warfarin use, serum potassium, hsCRP, phosphate, uric acid, and iPTH in model 1 [HR (95\% CI) 2.82 (1.31-6.29), $P=0.0078]$. However, the statistical significance of $\mathrm{Mg}<2.4 \mathrm{mg} / \mathrm{dl}$ was lost in model 2, which included the same variables as model 1 plus serum albumin.

The predictors of 3-year CV mortality identified in MHD patients by Cox proportional hazard analyses are shown in Table 3. The same independent variables in Table 2 were included in the univariate Cox models. In the univariate analyses, the age, dialysis vintage, $\log ($ CACS + 1), warfarin use, serum hsCRP, uric acid, $\mathrm{Mg}<2.4 \mathrm{mg} / \mathrm{dl}$, and serum albumin were found to be significantly associated with 3 -year $\mathrm{CV}$ mortality $(P<0.05)$. However, other variables, including the gender (male), presence of diabetes mellitus, urine volume $\geq 100 \mathrm{ml} /$ day, average ultrafiltration, serum potassium, phosphate, iPTH, and Log FGF23, were not. Multivariate analyses showed that $\mathrm{Mg}<2.4 \mathrm{mg} / \mathrm{dl}$ was significantly associated with 3 -year CV mortality, independent of age, dialysis vintage, $\log (\mathrm{CACS}+1)$, warfarin use, serum hsCRP, and uric acid in model 1 [HR (95\% CI): 4.47 (1.45-16.76), $P=0.0086$ ]. However, the statistical significance of $\mathrm{Mg}<2.4 \mathrm{mg} / \mathrm{dl}$ was lost in model 2 , which included the same variables as model 1 plus serum albumin.

\section{Discussion}

The estimation of total body magnesium stores based on serum levels can be problematic as this fraction is not necessarily readily exchangeable with other body compartments. However, the most common method of clinical assessment of magnesium balance remains the total $\mathrm{Mg}$ [4]. Recently, there has been an increasing number of clinical reports regarding the associations between $\mathrm{Mg}$ levels and mortality and CV mortality in HD patients. Most studies found that lower $\mathrm{Mg}$ levels were associated with increased all-cause and CV mortality [9, 13-15]. However, Ishimura et al. reported that all-cause and non-CV mortality (but not $\mathrm{CV}$ mortality) were associated with lower $\mathrm{Mg}$ levels [16]. Our study showed worse 3-year cumulative overall survival for all-cause and CV death in patients with hypomagnesemia $(\mathrm{Mg}<2.4 \mathrm{mg} / \mathrm{dl})$; however, the significance was lost when serum albumin quartile was incorporated in the models. Cox proportional hazard analyses in our study showed that $\mathrm{Mg}<2.4 \mathrm{mg} / \mathrm{dl}$ was a significant 3 -year all-cause mortality risk factor, independent of age, dialysis vintage, average ultrafiltration, $\log (\mathrm{CACS}+1)$, warfarin use, serum potassium, hsCRP, phosphate, uric acid, and iPTH. Furthermore, $\mathrm{Mg}<2.4 \mathrm{mg} / \mathrm{dl}$ was a significant predictor of 3-year $\mathrm{CV}$ death, independent of age, dialysis vintage, $\log (C A C S+1)$, warfarin use, serum hsCRP, and uric acid. However, upon inclusion of serum albumin in the models, the all-cause and CV mortality risk prediction of hypomagnesemia was lost. This indicates that hypomagnesemia alone was not an independent predictor of all-cause and $\mathrm{CV}$ mortality, but was associated with malnutrition. The median (IQR) age was 68 (60-78) years and the 3 -year cumulative survival rate was $73.3 \%$ in our subjects; these were consistent with the 3-year cumulative survival rate $(72.9 \%)$ in Japanese MHD patients for a similar median age [17]. This seems relevant for generalization of the results, at least in Japanese patients.

A cohort study of 142,555 Japanese HD patients by Sakaguchi et al. [8] and a study of 206 HD patients by Matias et al. [13] revealed that hypomagnesemia is a significant mortality risk factor, independent of malnutrition; this is inconsistent with our results. Notably, all three of those studies were prospective observational studies; the observational period was $1-2$ years in those studies 


\section{a Overall 3-year survival for cardiovascular mortality}

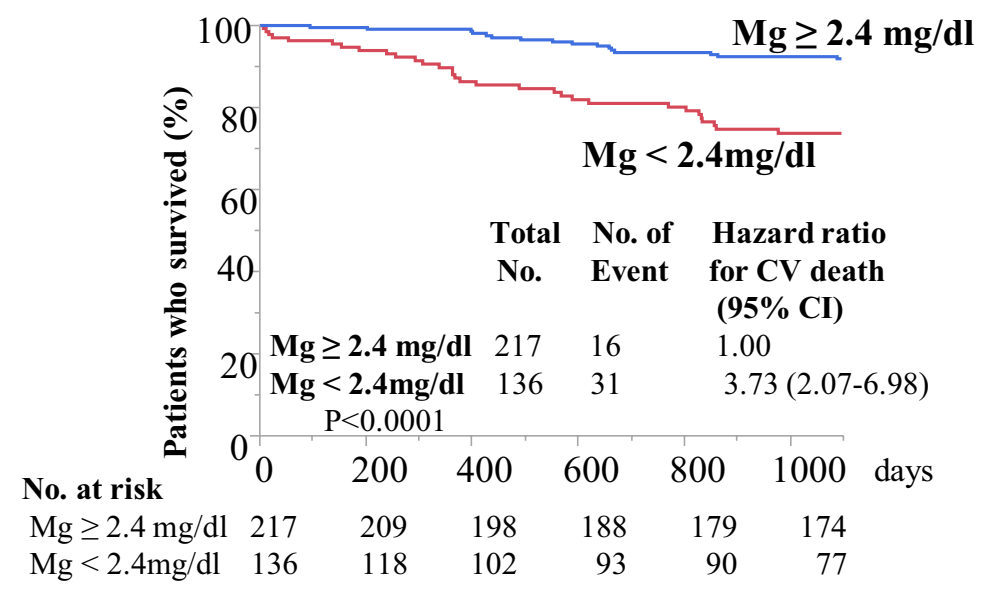

b Serum albumin of Q1: $3.0(2.7-3.2) \mathrm{g} / \mathrm{dl}$

d Serum albumin of Q3: $3.7(3.6-3.7) \mathrm{g} / \mathrm{dl}$
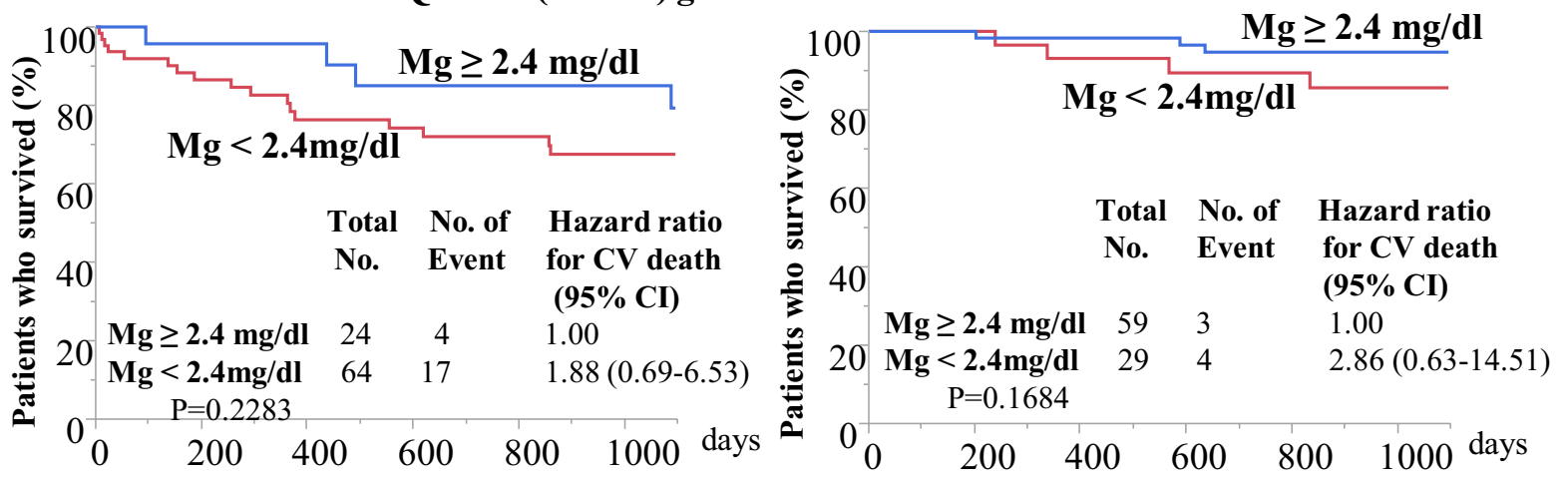

No. at risk No. at risk

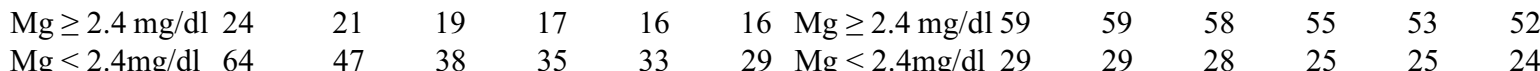

$\begin{array}{llllllllllll}\mathrm{Mg}<2.4 \mathrm{mg} / \mathrm{dl} & 64 & 47 & 38 & 35 & 33 & 29 & \mathrm{Mg}<2.4 \mathrm{mg} / \mathrm{dl} 29 & 29 & 28 & 25 & 25\end{array}$

c Serum albumin of Q2: $3.5(3.4-3.5) \mathrm{g} / \mathrm{dl}$

No. at risk

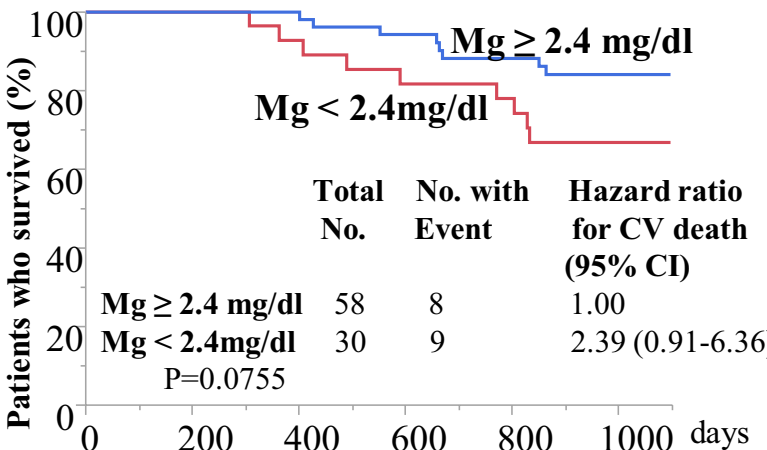

e Serum albumin of $Q 4: 3.9(3.8-3.9) \mathrm{g} / \mathrm{dl}$

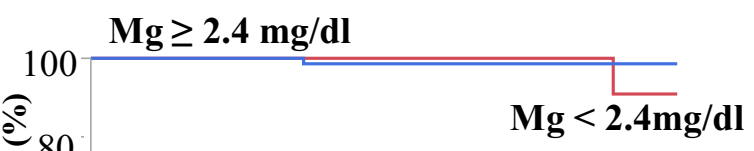

Total No. with Hazard ratio

No. Event for CV death $(95 \%$ CI)

1.00

$6.01(0.24-151.74)$

No. at risk

$\begin{array}{lllllllllllll}\mathrm{Mg} \geq 2.4 \mathrm{mg} / \mathrm{dl} 58 & 58 & 54 & 49 & 44 & 40 & \mathrm{Mg} \geq 2.4 \mathrm{mg} / \mathrm{dl} 76 & 73 & 70 & 70 & 69 & 69\end{array}$

$\begin{array}{llllllllllllll}\mathrm{Mg}<2.4 \mathrm{mg} / \mathrm{dl} & 30 & 30 & 26 & 23 & 22 & 16 & \mathrm{Mg}<2.4 \mathrm{mg} / \mathrm{dl} & 13 & 13 & 13 & 13 & 13 & 13\end{array}$ 
४Fig. 2 Kaplan-Meier overall 3-year survival for cardiovascular (CV) mortality (a) and 3-year survival for CV mortality in subgroups according to serum albumin quartiles (b-e). Overall survival for $\mathrm{CV}$ death was worse in patients with $\mathrm{Mg}$ values below the median value $(<2.4 \mathrm{mg} / \mathrm{dl}, n=136)$ than in patients with $\mathrm{Mg}$ values greater than the median value $(\geq 2.4 \mathrm{mg} / \mathrm{dl}, n=217)$. The hazard ratio $(95 \%$ confidence interval) for $\mathrm{CV}$ death was 3.73 (2.07-6.98), $P<0.0001$ (a). However, the significant difference for CV mortality was lost in subgroup analyses when serum albumin quartiles were incorporated (b-e). Mg, serum magnesium; No., numbers; CI, confidence interval

and 3 years in our study. It has been reported that MHD patients tend to exhibit higher Mg levels than healthy controls $[4,18]$. The frequency of hypermagnesemia $(>2.4 \mathrm{mg} / \mathrm{dl})$ in our study was $170 / 353(48.2 \%)$, which is lower than the frequencies reported by Sakaguchi et al. [87,993/142,555 (61.7\%)] [8] or Matias et al. [197/206 (95.5\%)] [13]. The different results in these studies may be explained by changes in magnesium balance in the analyzed patients, perhaps due to low food intake, processed foods with a low magnesium content in patients, and low dialysate magnesium concentration $(1 \mathrm{mEq} / \mathrm{l})$ in Japan, compared with the dialysate used by Matias et al. $(2.0 \mathrm{mEq} / \mathrm{l})$. There is a possibility that the lower frequency of hypermagnesemia in our study may mask some positive effect of $\mathrm{Mg}$ in our cohort. Sakaguchi et al. detected a $\mathrm{J}$-shaped relationship between $\mathrm{Mg}$ levels and mortality, in which $\mathrm{Mg}$ levels of $<2.7 \mathrm{mg} / \mathrm{dl}$ and $\geq 3.1 \mathrm{mg} / \mathrm{dl}$ were associated with increased risks of all-cause mortality [8]. Optimal Mg concentration in HD patients may be above the reference range for the general population. We agree with the suggestion by Sakaguchi et al. that it is important to determine both the lower and upper limits of the target range of $\mathrm{Mg}$ in $\mathrm{HD}$ patients [8], because hypermagnesemia has been linked to osteomalacia; moreover, activation of the calcium-sensing receptor results in lower PTH levels $[3,19]$. Further studies are needed to determine optimal $\mathrm{Mg}$ levels and dialysate magnesium concentrations for HD patients.

It has been reported that lower $\mathrm{Mg}$ levels are associated with reduced serum phosphorus, calcium, and albumin levels; thus, they might be indicative of malnutrition $[9,16$, 20]. It has also been reported that lower $\mathrm{Mg}$ levels are linked with poorer nutritional status and increased inflammation [21]. A large study found that hypomagnesemia $(<1.9 \mathrm{mg} /$ dl) conferred an increased risk of mortality solely in the presence of low-serum albumin levels $(<35 \mathrm{~g} / \mathrm{l})$ [22]. In our study, MHD patients with $\mathrm{Mg}<2.4 \mathrm{mg} / \mathrm{dl}$ had worse nutritional status, which comprised lower values of serum

Table 2 Predictors of 3-year all-cause mortality in maintenance hemodialysis patients, according to Cox proportional hazard analyses $(n=353)$

\begin{tabular}{|c|c|c|c|c|c|c|c|c|c|}
\hline \multirow[t]{3}{*}{ Independent variable } & \multirow{2}{*}{\multicolumn{3}{|c|}{ Univariate analyses }} & \multicolumn{6}{|c|}{ Multivariate analyses } \\
\hline & & & & \multicolumn{3}{|c|}{ Model 1} & \multicolumn{3}{|c|}{ Model 2} \\
\hline & HR & $95 \%$ CI & $P$ & HR & $95 \%$ CI & $P$ & HR & $95 \% \mathrm{CI}$ & $P$ \\
\hline Age (years) & 1.08 & $1.06-1.11$ & $<0.0001$ & 1.07 & $1.03-1.12$ & 0.0002 & 1.06 & $1.01-1.10$ & 0.0088 \\
\hline Dialysis vintage (months) & 1.00 & $0.99-1.00$ & $<0.0091$ & 1.00 & $0.99-1.00$ & 0.5028 & 1.00 & $0.99-1.00$ & 0.8750 \\
\hline Average ultrafiltration $(\mathrm{ml} / \mathrm{kg} / \mathrm{h})$ & 0.93 & $0.86-0.99$ & 0.0295 & 0.99 & $0.87-1.13$ & 0.8700 & 0.98 & $0.87-1.12$ & 0.8109 \\
\hline $\log (\mathrm{CACS}+1)$ & 2.07 & $1.24-3.84$ & 0.0036 & 1.74 & $1.01-3.26$ & 0.0472 & 1.99 & $1.03-3.84$ & 0.0246 \\
\hline Warfarin use & 2.51 & $1.47-4.08$ & 0.0012 & 3.88 & $1.75-8.17$ & 0.0013 & 4.52 & $2.03-9.54$ & 0.0004 \\
\hline Serum potassium $(\mathrm{mEq} / \mathrm{l})$ & 0.60 & $0.45-0.79$ & 0.0002 & 1.28 & $0.70-2.31$ & 0.4172 & 1.53 & $0.81-2.87$ & 0.1878 \\
\hline Serum hsCRP (mg/dl) & 1.57 & $1.39-1.77$ & $<0.0001$ & 1.20 & $0.88-1.57$ & 0.2257 & 1.12 & $0.84-1.49$ & 0.4623 \\
\hline Serum phosphate (mg/dl) & 0.73 & $0.63-0.84$ & $<0.0001$ & 1.07 & $0.78-1.46$ & 0.6795 & 1.17 & $0.86-1.60$ & 0.3191 \\
\hline Serum uric acid (mg/dl) & 0.63 & $0.53-0.75$ & $<0.0001$ & 0.79 & $0.55-1.10$ & 0.1658 & 0.87 & $0.62-1.22$ & 0.4152 \\
\hline Intact parathyroid hormone $(\mathrm{pg} / \mathrm{ml})$ & 1.00 & $0.99-1.00$ & 0.0357 & 0.99 & $0.99-1.00$ & 0.9694 & 1.00 & $0.99-1.00$ & 0.8527 \\
\hline Serum $\mathrm{Mg}<2.4 \mathrm{mg} / \mathrm{dl}$ & 2.79 & $1.84-4.27$ & $<0.0001$ & 2.82 & $1.31-6.29$ & 0.0078 & 2.17 & $0.96-5.02$ & 0.0633 \\
\hline Serum albumin $(\mathrm{g} / \mathrm{dl})$ & 0.13 & $0.10-0.19$ & $<0.0001$ & & & & 0.21 & $0.09-0.49$ & 0.0007 \\
\hline Gender (male) & 0.87 & $0.57-1.35$ & 0.5262 & & & & & & \\
\hline Diabetes mellitus & 1.39 & $0.92-2.09$ & 0.1205 & & & & & & \\
\hline Urine volume $\geq 100 \mathrm{ml} /$ day & 0.67 & $0.39-1.10$ & 0.1136 & & & & & & \\
\hline Log FGF23 (pg/ml) & 1.00 & $0.99-1.00$ & 0.1086 & & & & & & \\
\hline
\end{tabular}

Model 1 included age, dialysis vintage, average ultrafiltration, Log (CACS + 1), warfarin use, serum potassium, hsCRP, phosphate, uric acid, intact parathyroid hormone, and serum $\mathrm{Mg}<2.4 \mathrm{mg} / \mathrm{dl}$, which exhibited significance in the univariate analyses; serum albumin was excluded. Model 2 included the same variables as model 1 plus serum albumin

$\mathrm{Mg}$, magnesium; Diabetes mellitus, presence of diabetes mellitus; Average ultrafiltration $(\mathrm{ml} / \mathrm{kg} / \mathrm{h})$, average ultrafiltration/body weight before treatment in the first hemodialysis session of the week in September $2014(\mathrm{ml} / \mathrm{kg} / \mathrm{h})$; CACS, coronary artery calcium score; Warfarin use, current use of warfarin; hsCRP, high-sensitivity C-reactive protein; FGF23, intact fibroblast growth factor 23; HR, hazard ratio; CI, confidence interval 
Table 3 Predictors of 3-year cardiovascular mortality in maintenance hemodialysis patients, according to Cox proportional hazard analyses $(n=353)$

\begin{tabular}{|c|c|c|c|c|c|c|c|c|c|}
\hline \multirow[t]{3}{*}{ Independent variable } & \multirow{2}{*}{\multicolumn{3}{|c|}{ Univariate analyses }} & \multicolumn{6}{|c|}{ Multivariate analyses } \\
\hline & & & & \multicolumn{3}{|c|}{ Model 1} & \multicolumn{3}{|c|}{ Model 2} \\
\hline & HR & $95 \% \mathrm{CI}$ & $P$ & HR & $95 \% \mathrm{CI}$ & $P$ & HR & $95 \% \mathrm{CI}$ & $P$ \\
\hline Age (years) & 1.08 & $1.05-1.11$ & $<0.0001$ & 1.09 & $1.03-1.18$ & 0.0058 & 1.08 & $1.01-1.17$ & 0.0251 \\
\hline Dialysis vintage (months) & 1.00 & $0.99-1.00$ & 0.0091 & 1.00 & $1.00-1.01$ & 0.5429 & 1.00 & $0.99-1.01$ & 0.8450 \\
\hline $\log (\mathrm{CACS}+1)$ & 2.94 & $1.21-9.21$ & 0.0126 & 2.46 & $1.03-7.27$ & 0.0416 & 2.79 & $1.06-9.06$ & 0.0372 \\
\hline Warfarin use & 2.93 & $1.42-5.58$ & 0.0049 & 6.21 & $1.95-19.13$ & 0.0029 & 7.27 & $2.22-23.04$ & 0.0017 \\
\hline Serum hsCRP (mg/dl) & 1.57 & $1.29-1.84$ & $<0.0001$ & 1.06 & $0.65-1.50$ & 0.7924 & 1.03 & $0.58-1.40$ & 0.8834 \\
\hline Serum uric acid (mg/dl) & 0.69 & $0.54-0.87$ & 0.0012 & 1.18 & $0.81-1.73$ & 0.3979 & 1.50 & $0.99-2.33$ & 0.0568 \\
\hline Serum $\mathrm{Mg}<2.4 \mathrm{mg} / \mathrm{dl}$ & 3.73 & $2.07-6.98$ & $<0.0001$ & 4.47 & $1.45-16.76$ & 0.0086 & 2.56 & $0.72-10.36$ & 0.1485 \\
\hline Serum albumin $(\mathrm{g} / \mathrm{dl})$ & 0.15 & $0.09-0.24$ & $<0.0001$ & & & & 0.15 & $0.04-0.57$ & 0.0062 \\
\hline Gender (male) & 0.83 & $0.46-1.54$ & 0.5424 & & & & & & \\
\hline Diabetes mellitus & 1.47 & $0.83-2.62$ & 0.1859 & & & & & & \\
\hline Urine volume $\geq 100 \mathrm{ml} /$ day & 0.87 & $0.48-1.68$ & 0.6725 & & & & & & \\
\hline Average ultrafiltration $(\mathrm{ml} / \mathrm{kg} / \mathrm{h})$ & 0.94 & $0.85-1.03$ & 0.1947 & & & & & & \\
\hline Serum potassium (mEq/l) & 0.69 & $0.47-1.01$ & 0.0565 & & & & & & \\
\hline Serum phosphate (mg/dL) & 0.93 & $0.76-1.14$ & 0.4977 & & & & & & \\
\hline Intact parathyroid hormone $(\mathrm{pg} / \mathrm{ml})$ & 1.00 & $0.99-1.00$ & 0.5725 & & & & & & \\
\hline Log FGF23 (pg/ml) & 1.00 & $0.99-1.00$ & 0.3003 & & & & & & \\
\hline
\end{tabular}

Model 1 included age, dialysis vintage, $\log (\mathrm{CACS}+1)$, warfarin use, serum hsCRP, uric acid, and serum $\mathrm{Mg}<2.4 \mathrm{mg} / \mathrm{dl}$, which exhibited significance in the univariate analyses; serum albumin was excluded. Model 2 included the same variables as model 1 plus serum albumin

$\mathrm{Mg}$, magnesium; Diabetes mellitus, presence of diabetes mellitus; Average ultrafiltration $(\mathrm{ml} / \mathrm{kg} / \mathrm{h})$, average ultrafiltration/body weight before treatment in the first hemodialysis session of the week in September $2014(\mathrm{ml} / \mathrm{kg} / \mathrm{h})$; CACS, coronary artery calcium score; Warfarin use, current use of warfarin; hsCRP, high-sensitivity C-reactive protein; FGF23, intact fibroblast growth factor 23; HR, hazard ratio; CI, confidence interval

albumin, nPNA, GNRI, phosphate, and uric acid, compared with patients with $\mathrm{Mg} \geq 2.4 \mathrm{mg} / \mathrm{dl}$. Taken together with the results of the previous reports $[9,16,20-22]$, our findings indicate that nutritional factors greatly influence hypomagnesemia, and that such factors might partly contribute to the poor outcomes described by Courivaud et al. [11]. Thus, hypomagnesemia appears to be correlated with mortality; whether Mg plays a causal role in this relationship remains unclear $[4,11]$.

The presence of diabetes mellitus, FGF23 levels, and existing residual renal function were not significant predictors for 3-year all-cause and CV mortality in MHD patients in our study. We cannot completely exclude relevant bias in the analyses, but we have contemplated our results as below. The reported 5-year cumulative survival rates of HD patients with and without diabetes were $47 \%$ versus $31 \%$, while corresponding 10 -year cumulative survival rates were $22 \%$ versus $31 \%[P=0.03]$; the paths of the two groups were divergent at 5 years, suggesting that patients with diabetes may experience early mortality [23]. Early mortality in diabetic HD patients may be partly explained by the lack of an association between the presence of diabetes mellitus and mortality in our study, because our subjects were not incident
HD patients and the median (IQR) dialysis vintage was 75 (32-151) months. The association of serum FGF23 levels and mortality in HD patients has been frequently described $[24,25]$; however, no association was reported by Olauson et al. [26], which is consistent with our results. Discrepancies between these studies might be partly explained by the contributions of previous $\mathrm{CV}$ diseases, residual renal function levels, variations in the prevalence of diabetes [27], and racial differences. Urine volume $\geq 100 \mathrm{ml} /$ day was used as a surrogate marker for residual renal function in this study, as in previous reports $[28,29]$. An association between residual renal function (urine volume $\geq 100 \mathrm{ml} /$ day) and mortality in MHD patients was not observed in our study, in contrast to previous reports [28, 29]; this may be related to the lower frequency of patients with residual renal function in our study [87/353 (24.6\%) patients].

Our data did not show a significant difference of CACS between patients with $\mathrm{Mg}<2.4 \mathrm{mg} / \mathrm{dl}$ and patients with $\mathrm{Mg} \geq 2.4 \mathrm{mg} / \mathrm{dl}$, in contrast to previous experimental studies [5-7]. However, we suspect that the lack of a cross-sectional association does not exclude a potential impact of persistently low Mg levels on CACS progression. 
This study has several limitations. First, the study was a single analysis of laboratory values only at baseline. Therefore, there was no time-averaged analysis of laboratory data, and the influence of a single serum sample of magnesium, FGF23, or potassium value on 3-year all-cause and CV mortality might exhibit wide variation. Second, because the subjects were all Japanese MHD patients, the results might not be applicable to other populations. Third, the sample size and number of deaths were relatively small; therefore, the Cox regression analyses were restricted to a limited number of potential confounders. Fourth, there was no information regarding oral magnesium intake among these patients.

In conclusion, MHD patients with hypomagnesemia showed significantly worse 3-year cumulative survival for all-cause and CV death. Importantly, hypomagnesemia was not an independent risk factor for all-cause and CV mortality, but was associated with malnutrition in MHD patients.

Acknowledgements We thank Mr. Kozo Fukuda, and Miss Yukari Suga in Ichiyokai Ichiyokai clinic for their statistical assistance.

Funding There was no funding to the study.

\section{Compliance with ethical standards}

Conflict of interest All the authors declare that they have no conflict of interest.

Ethical approval All procedures performed in studies involving human participants were in accordance with the ethical standards of the institutional and/or national research committee and with the 1964 Helsinki declaration and its later amendments or comparable ethical standards. The committee on human research at Ichiyokai Hospital approved the study protocol (Authorization No. 201706)

Informed consent Informed consent was obtained from all individual participants included in this study.

OpenAccess This article is distributed under the terms of the Creative Commons Attribution 4.0 International License (http://creativeco mmons.org/licenses/by/4.0/), which permits unrestricted use, distribution, and reproduction in any medium, provided you give appropriate credit to the original author(s) and the source, provide a link to the Creative Commons license, and indicate if changes were made.

\section{References}

1. Hamano N, Komaba H, Fukagawa M (2017) Magnesium as a new player in CKD: too little is as bad as too much? Kidney Int 92:1034-1036

2. Sakaguchi Y, Hamano T, Isaka Y (2018) Magnesium in hemodialysis patients: a new understanding of the old problem. Contrib Nephrol 196:58-63

3. Alhosaini M, Leehey DJ (2015) Magnesium and dialysis: the neglected cation. Am J Kidney Dis 66:523-531

4. Misra PS, Nessim SJ (2017) Clinical aspects of magnesium physiology in patients on dialysis. Semin Dial 30:438-445
5. Montezano AC, Zimmerman D, Yusuf H, Burger D, Chignalia AZ, Wadhera V, van Leeuwen FN, Touyz RM (2010) Vascular smooth muscle cell differentiation to an osteogenic phenotype involves TRPM7 modulation by magnesium. Hypertension 56:453-462

6. Pasch A, Farese S, Gräber S, Wald J, Richtering W, Floege J, Jahnen-Dechent W (2012) Nanoparticle-based test measures overall propensity for calcification in serum. J Am Soc Nephrol 23:1744-1752

7. Diaz-Tocados JM, Peralta-Ramirez A, Rodríguez-Ortiz ME et al (2017) Dietary magnesium supplementation prevents and reverses vascular and soft tissue calcifications in uremic rats. Kidney Int 92:1084-1099

8. Sakaguchi Y, Fujii N, Shoji T, Hayashi T, Rakugi H, Isaka Y (2014) Hypomagnesemia is a significant predictor of cardiovascular and non-cardiovascular mortality in patients undergoing hemodialysis. Kidney Int 85:174-181

9. Lacson E Jr, Wang W, Ma L, Passlick-Deetjen J (2015) Serum magnesium and mortality in hemodialysis patients in the United States: a cohort study. Am J Kidney Dis 66:1056-1066

10. Schmaderer C, Braunisch MC, Suttmann Y, Lorenz G, Pham D, Haller B, Angermann S, Matschkal J, Renders L, Baumann M, Braun JR, Heemann U, Küchle C (2017) Reduced mortality in maintenance haemodialysis patients on high versus low dialysate magnesium. A pilot study. Nutrients 9:E926

11. Courivaud C, Davenport A (2014) Magnesium and the risk of all-cause and cardiac mortality in hemodialysis patients: agent provocateur or innocent bystander? Kidney Int 85:17-20

12. Agatston AS, Janowitz WR, Hildner FJ, Zusmer NR, Viamonte M Jr, Detrano R (1990) Quantification of coronary artery calcium using ultrafast computed tomography. J Am Coll Cardiol $15: 827-832$

13. João Matias $P$, Azevedo A, Laranjinha I, Navarro D, Mendes M, Ferreira C, Amaral T, Jorge C, Aires I, Gil C, Ferreira A (2014) Lower serum magnesium is associated with cardiovascular risk factors and mortality in haemodialysis patients. Blood Purif 38:244-252

14. de Roij van Zuijdewijn CL, Grooteman MP, Bots ML, Blankestijn PJ, Steppan S, Büchel J, Groenwold RH, Brandenburg V, van den Dorpel MA, Ter Wee PM, Nubé MJ, Vervloet MG (2015) Serum magnesium and sudden death in European hemodialysis patients. PLoS ONE 10:e0143104

15. Selim GN, Spasovski G, Tozija L, Georgievska-Ismail L, Zafirova-Ivanovska B, Masin-Spasovska J, Rambabova-Busletic I, Petronijevic Z, Dzekova-Vidimliski P, Ristovska V, Pusevski V, Stojceva-Taneva O (2017) Hypomagnesemia and cause-specific mortality in hemodialysis patients: 5-year follow-up analysis. Int J Artif Organs 40:542-549

16. Ishimura E, Okuno S, Kitatani K, Tsuchida T, Yamakawa T, Shioi A, Inaba M, Nishizawa Y (2007) Significant association between the presence of peripheral vascular calcification and lower serum magnesium in hemodialysis patients. Clin Nephrol 68:222-227

17. Masakane I, Nakai S, Ogata S, Kimata N, Hanafusa N, Hamano T, Wakai K, Wada A, Nitta K (2015) An overview of regular dialysis treatment in Japan (As of 31 December 2013). Ther Apher Dial 19:540-574

18. Navarro-González JF (1998) Magnesium in dialysis patients: serum levels and clinical implications. Clin Nephrol 49:373-378

19. Gonella M, Ballanti P, Della Rocca C, Calabrese G, Pratesi G, Vagelli G, Mazzotta A, Bonucci E (1988) Improved bone morphology by normalizing serum magnesium in chronically hemodialyzed patients. Miner Electrolyte Metab 14:240-245

20. Liu F, Zhang X, Qi H, Wang J, Wang M, Zhang Y, Yan H, Zhuang S (2013) Correlation of serum magnesium with cardiovascular 
risk factors in maintenance hemodialysis patients-a cross-sectional study. Magnes Res 26:100-108

21. Fein P, Suda V, Borawsky C, Kapupara H, Butikis A, Matza B, Chattopadhyay J, Avra MM (2010) Relationship of serum magnesium to body composition and inflammation in peritoneal dialysis patients. Adv Perit Dial 26:112-115

22. Li L, Streja E, Rhee CM, Mehrotra R, Soohoo M, Brunelli SM, Kovesdy CP, Kalantar-Zadeh K (2015) Hypomagnesemia and mortality in incident hemodialysis patients. Am J Kidney Dis 66:1047-1055

23. Browne OT, Allgar V, Bhandari S (2014) Analysis of factors predicting mortality of new patients commencing renal replacement therapy 10 years of follow-up. BMC Nephrol 15:20

24. Gutiérrez OM, Mannstadt M, Isakova T, Rauh-Hain JA, Tamez H, Shah A, Smith K, Lee H, Thadhani R, Jüppner H, Wolf M (2008) Fibroblast growth factor 23 and mortality among patients undergoing hemodialysis. N Engl J Med 359:584-592

25. Jean G, Terrat JC, Vanel T, Hurot JM, Lorriaux C, Mayor B, Chazot C (2009) High levels of serum fibroblast growth factor
(FGF)-23 are associated with increased mortality in long haemodialysis patients. Nephrol Dial Transplant 24:2792-2796

26. Olauson H, Qureshi AR, Miyamoto T, Barany P, Heimburger O, Lindholm B, Stenvinkel P, Larsson TE (2010) Relation between serum fibroblast growth factor-23 level and mortality in incident dialysis patients: are gender and cardiovascular disease confounding the relationship? Nephrol Dial Transplant 25:3033-3038

27. Kojima F, Uchida K, Ogawa T, Tanaka Y, Nitta K (2008) Plasma levels of fibroblast growth factor-23 and mineral metabolism in diabetic and non-diabetic patients on chronic hemodialysis. Int Urol Nephrol 40:1067-1074

28. Shemin D, Bostom AG, Laliberty P, Dworkin LD (2001) Residual renal function and mortality risk in hemodialysis patients. Am J Kidney Dis 38:85-90

29. Lee MJ, Park JT, Park KS, Kwon YE, Oh HJ, Yoo TH, Han SH, Kim YL, Kim YS, Yang CW, Kim NH, Kang SW (2017) Prognostic value of residual urine volume, GFR by 24-hour urine collection, and eGFR in patients receiving dialysis. Clin J Am Soc Nephrol 12:426-443 